Open Access

\title{
The Vitruvian Man of Leonardo da Vinci as a model of innovative entrepreneurship at the intersection of business, art and technology
}

Mariella C. Remund ${ }^{1}$, Marta Peris-Ortiz ${ }^{2^{*}}$ and Hans-Jurgen Gehrke ${ }^{3}$

\author{
* Correspondence: \\ mperis@doe.upv.es \\ ${ }^{2}$ Universitat Politècnica de València, \\ Camino de Vera, s/n, 46022 \\ Valencia, Spain \\ Full list of author information is \\ available at the end of the article
}

\begin{abstract}
The vital role of entrepreneurship for economic growth and its impact for job creation in mature and developing economies is widely recognized and quantified (OECD, Entrepreneurship and Business Statistics, 2015).

According to Get2growth data (How Many Startups Are There?, 2015), 100 million start-ups are created each year of which 1.35\% are technology-based companies, and according to the Kauffman Index of Entrepreneurial Activity (Fairlie, 2013), almost a quarter of new businesses in the USA were started by entrepreneurs aged 55 and older.

Survival following failure data for start-ups are numerous and complex in the interpretation, and data presented by the Statistic Brain (Startup business failure rate by industry, 2015) show a 55\% failure rate within the fifth year.

Entrepreneurship is important for growth but sustainable entrepreneurship is hard to achieve.

This paper, by means of a case study of a German private art museum "Kunstmuseum Gehrke-Remund", analyzes the disruptive methods, both atypical and contrary to the mainstream art industry, developed to ensure the sustainable success of such an innovative endeavor. Our analyses and results contribute to the understanding of the building blocks and roadmap designed by the Kunstmuseum to successfully enter the elitist contemporary art industry, as an outsider, and provide an early indication that such methods can be theoretically replicated in other industries by other entrepreneurs.
\end{abstract}

Keywords: Entrepreneurship, Disruptive innovation, Start-up, Art, Contemporary art, Business, Technology, Art museum, Private museums, Kunstmuseum Gehrke-Remund, Vitruvian man, Sustainable growth, Business model, Value creation, Experience map, Perfect execution, Creativity, Minimum viable product

\section{Introduction}

The selection of the Vitruvian Man (Gallery of the Academy in Venice, dated approximately in 1490) as the title and as the basic reference for this paper, has the aim to highlight the interrelation between art and science, and the close relationship between both forms of activity with the economy sector (production and trade) and entrepreneurship.

Since 1776, the year in which Adam Smith published "The Wealth of Nations" up to the work by Samuelson "Foundations of Economic Analysis" (1947) and up to modern

(c) The Author(s). 2017 Open Access This article is distributed under the terms of the Creative Commons Attribution 4.0 International License (http://creativecommons.org/licenses/by/4.0/), which permits unrestricted use, distribution, and reproduction in any medium provided you give appropriate credit to the original author(s) and the source, provide a link to the Creative Commons license, and indicate if changes were made. 
times, economy and business fields have sought their own space as scientific or as an organized and systematic knowledge and have emphasized that the essential purpose of the entrepreneur or businessman is to earn profits. For this reason, it is certainly necessary to be efficient in the use of resources (minimize costs) and be able to obtain the relevant information from markets to offer the products wherever there is the highest demand (and best price); however, this search for profits, as the only important objective (the analytical simplification inherent to science) leaves-concealed in a black box-everything which demonstrates the close similarities between creativity, art, science and entrepreneurship.

Accordingly, the entrepreneurial activity or entrepreneurship can be considered as an expression of the capacity of human creation which is materialized in the world of business or in other fields of society. When we mention that it is necessary to obtain the relevant information from the markets to offer the products wherever there is the highest demand and best price, this is within the discovery of the opportunity concept of entrepreneurship (Shane and Venkataraman, 2000); when we say that there must be efficiency in the use of resources thus minimizing the costs, this corresponds to the new combinations of factors which are mentioned by Schumpeter $(1934,1950)$ in his vision of creative destruction and belongs to the concept of the corporate entrepreneur of Hayton $(2005,2006)$. The vision capable of discovering opportunity permits rearranging the world and the trading of goods, as well as the corporate entrepreneur, through the new combinations of factors, inaugurates possibilities which were formerly nonexistent or innovates by applying new scientific discoveries. In the business world, this creativity is nothing other than the expression of the human capacity of creation and production in the context of markets.

These same ideas, in a more explicit or implicit way, are found in Penrose (1959) when he refers to the executive's mind (his creativity) as one of the essential resources of the company; in Weick (1969), through the concept of enactment, as the capacity so that the best proposals and initiatives succeed concerning the businesses in the ecological environment in which they compete; or in Child $(1972,1997)$ by means of his concept of strategic choice. However, the business sectors and the markets in which they compete have rules which require disciplining creativity (or to discipline the behaviors): the demand for positive benefits in order to continue the activity (Tracey et al., 2011). This indispensable discipline, which obliges obtaining more resources than those which are consumed in a project, frequently ends up suppressing the creativity or it is insufficient in specific circumstances, and this explains the $55 \%$ rate of business start-ups which disappear in the first 5 years of activity (Statistic Brain, 2015).

The market has its rules and selects the businesses-the forms of technical, organizational, social and economic creativity-which can survive in a complex environment, in which the markets depend on the economic cycles and/or the way in which they are managed by public policies. And nature also has its rules and its ecological limits, which although they still do not represent insurmountable physical limits for creativity and development in business sectors (although the legal limitations are increasingly greater), they already act and are operational, by means of culture: the awareness has spread of the planet's limits and the need for its conservation (Martin, 2016; Mont 2004) and this modifies the consumers' behaviors and obliges them to change the forms of creativity and production in the business world. 
This leads us once more to the concept of the Vitruvian Man, as the compendium of symmetries and balances which must be achieved and harmonized in the social, economic and business fields, in order to implement the experience in business sectors, the know-how of science and technology, and the humanist dimension of development. This convergence involves a culture which simultaneously permits enhancing the welfare and the sustainability. A culture, if we manage to base it on the attributes of the Vitruvian Man, will be increasingly characterized by the rise of intangibles in our consumer basket.

Although the literature is rich in templates for museums' strategic planning, feasibility studies and physical room planning, the supplied knowledge fails to address the current challenges and dilemmas faced by contemporary art museums worldwide. Recent literature research shows that current dilemmas of museums are addressed with mainstream solutions. This paper will introduce a new business and cultural model which disrupts all currently attempted solutions, based on the case of a start-up private museum in Germany by using the Da Vinci Vitruvian Man design as a template to illustrate how knowledge in art, business and science must overlap in equal and balanced parts to design the perfect visitors' experience and create a sustainable value proposition.

In a globalized world like today, in which two million people are born every day, the challenges which must be surpassed to approach these balances suggested by da Vinci are daunting. To a large degree, the values of harmony and culture depend on the forms of social organization which the most advanced governments of the planet are far from achieving and whose improvement can only be consistent and long lasting if it is the result of welfare culture.

This paper has four sections. The first section describes, by means of Leonardo da Vinci's design, The Vitruvian Man, three elements (art, business and science) as equally essential building blocks to design a successful start-up company and its product offerings. The first section also provides an overview of the mainstream contemporary art museum market in Germany, Austria and Switzerland, the market statistics; the challenges; and the solutions to face such dilemmas. The Vitruvian Man model is used as an example to describe and visualize the business and cultural models of existing contemporary art museums and their gaps. The second section describes the paper's objectives and methodology. The third section describes and analyses the museum of the case study, the Kunstmuseum. This section outlines in detail how the start-up Kunstmuseum was designed to challenge the industry rules of the mainstream contemporary art museums, which industry features were eliminated and which new disruptive features were introduced and applied. The traditional model of Minimum Viable Product (MVP) finds a new application to create added value to the product offerings and visitors' experience. The last section features the paper's conclusions and its limitations and provides suggestions for further research.

\section{Background and context}

The Vitruvian Man (Fig. 1), drawn by Leonardo Da Vinci around 1490, is a symbol of harmony, a canon of proportions and the epitome of perfection. The drawing is surrounded by notes based on the works of the Roman architect Vitruvius who lived during the first century BC. 


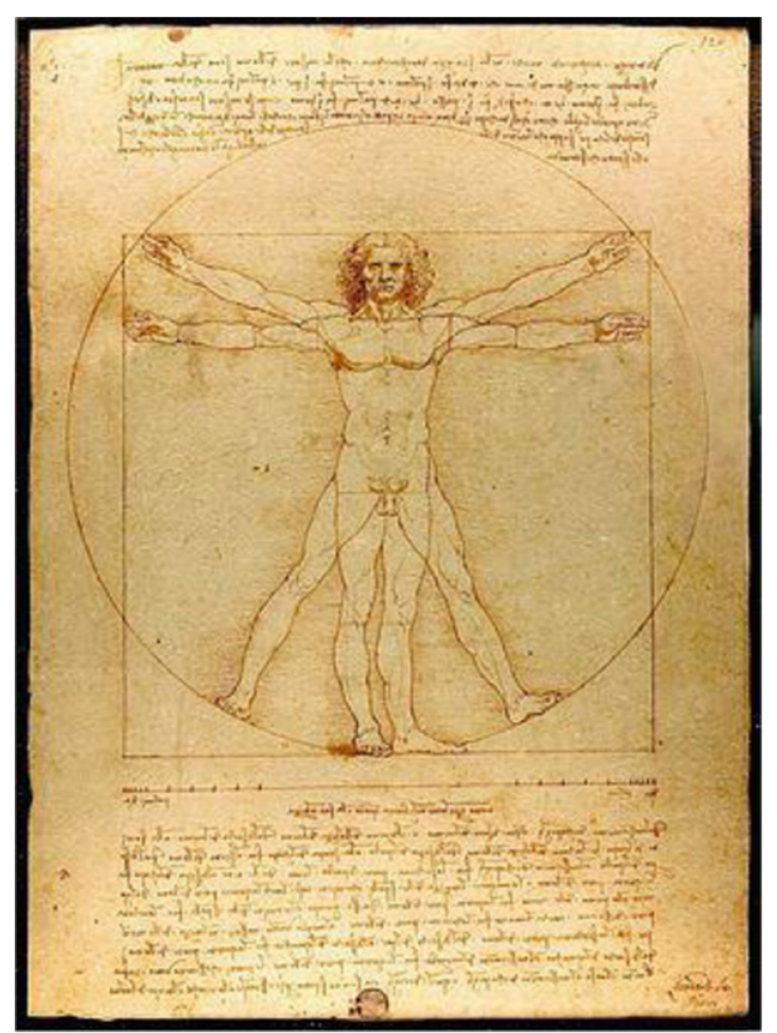

Fig. 1 Drawing of Vitruvian Man, Leonardo da Vinci, 1490

The image of the Vitruvian Man depicts the blend of art and science during the Renaissance and forms the basis of Renaissance proportions theories in art and architecture. The drawing attempts to illustrate the idea, set forth by Vitruvius, that the human body can be made to fit inside a circle and a square. It is much more than a geometrical challenge; the Leonardo ink drawing depicts a male figure whose outstretched limbs touch the circumference of a circle and the edges of a square. "There is a changing perspective in the work: it is static in structure but dynamic in its presentation of a moving, living man" (Campbell, 2016).

Since the original drawing of the Vitruvian Man was meant to represent the intersection of heaven, the circle, and of man, the square, in this paper, the image of the Vitruvian Man has been adopted to illustrate what innovative entrepreneurs should strive for, a sustainable value creation at the intersection of three dimensions representing business, art and science. Design thinking should be the bedrock of a start-up company in order to achieve the intersection of art, business and technology. The theoretical model of the Vitruvian Man will be explained and discussed; likewise, its application to the case of a private Art Museum in Germany will be evaluated by comparing and contrasting the elements which constitute the value proposition of the Art $\mathrm{Mu}$ seum in the case study with the elements at the foundation of mainstream contemporary art museums.

Regardless of the nature of the product or services offered, innovative entrepreneurs, who aim to develop a sustainable company, should combine the following three elements in their value proposition: business expertise, humanistic thinking and knowledge of science. 
Business expertise is vital for market intelligence, strategic planning, target groups selection, segmentation, positioning, design of customers' experience and customers' delight, processes designed for efficiency and effectiveness and fair and sustainable supply chain management. In addition, the mastery of financing, taxation and accounting principles is a must for entrepreneurs.

Humanistic thinking is equally important to design beauty and harmony in the company, in the products themselves, in the processes, and ultimately to design the products as artworks. Considerations of social justice, sustainability, and respect for the environment and the community at large are as important as financial skills.

Knowledge of science will enable the use of technology for efficiency, perfect execution, customers' reach, communication, feedback via social media and control mechanisms.

Start-ups based only on commercial or technology ideas are no longer competitive and eventually will not survive (Get2growth, 2015; OECD, 2015). In addition, start-ups that mainly focus their operational activities and execution on commercial or technology development are not creating the basis for a sustainable future, as the following case will demonstrate.

Innovative entrepreneurs, like the Vitruvian Man drawing by Leonardo, need to be at the intersection of business, art and technology and need to consider them in equal parts in the design, inception and execution of their endeavor (Fig. 2). The more the three elements overlap, the more the companies will be innovative and competitive and have sustainable staying power. The more the three elements overlap, the more differentiated the company's value proposition will be and the more difficult it will be for competitors to copy the product offering.

Considering the contemporary art world in business terms, it has been in a growth stage since the early 2000s. In 2015, sales of contemporary art from both art galleries and auctions reached a record high of 66 billion dollar revenues (D'Angelo and Schlenker, 2015).

In Germany, which is the country of the described case, since 1990, the number of museums has doubled to reach 6358 museums, of which 700 new art museums were opened during this time frame (Sayah, 2015). Fifty percent of the world's private contemporary art museums were founded between 2001 and 2010, and another 18\% have been founded since 2010 (Sutton, 2016).

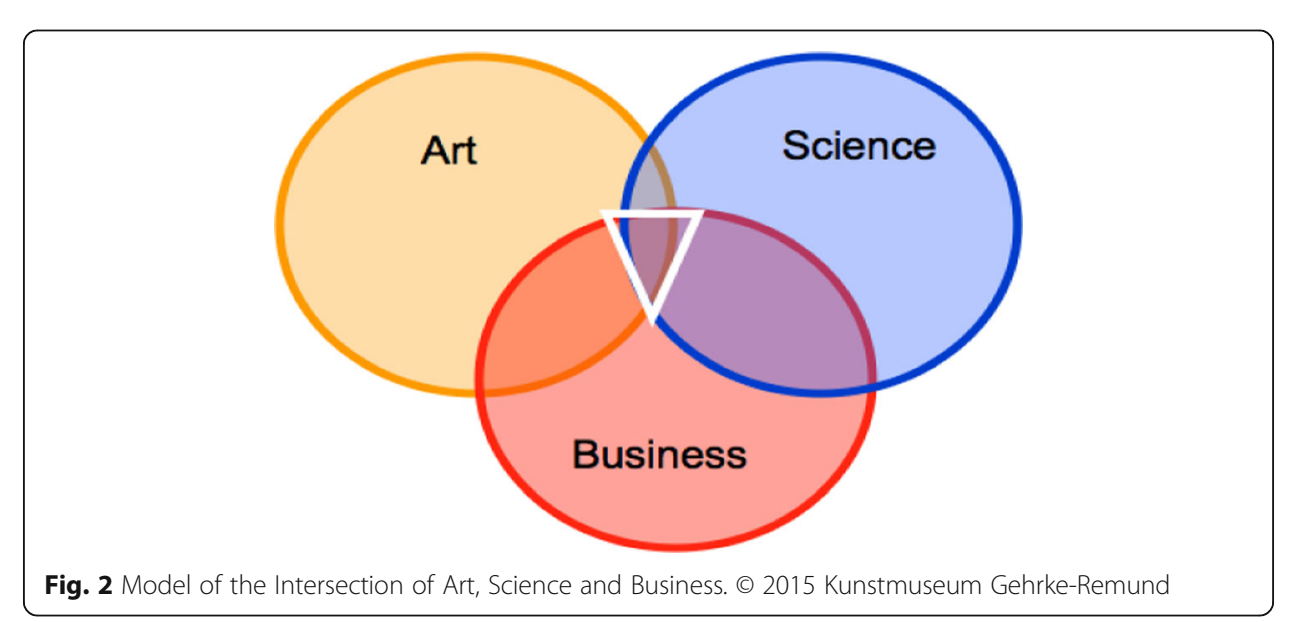


The current key players in contemporary art are galleries, museums, auction houses, private collectors and artists. Historically, during the Renaissance, the key players in art were the European royal houses, the Popes, the wealthy bourgeois families and the artists. Nowadays, beyond being a traditional status symbol for affluence, contemporary art has become an alternative investment channel for capital protection and growth.

Museums have the public scope and fourfold missions to collect, archive, conserve and display artworks. Nowadays, contemporary art museums worldwide share the same business- and technology-related challenges: ability to attract paying visitors, digitalization of their exhibits and the number of objects in their archives. Today's contemporary art museums are object-driven, heavy on assets and heavy on personnel.

A European art and copyright expert postulated that something is wrong in the world of contemporary art (Raue, 2010); he addressed the sustainability of contemporary art and the scope of art museums by stating that contemporary art should not be in art museums, it belongs in private collections or in public galleries. Art museums should exhibit artworks that are worth conserving and have gained recognition over time, independently from fashion and hype. He mentioned that today's contemporary art museums should display the works of classic modern artists (1900-1950) who have already gained an artistic and sustainable recognition and relevance.

There are three key dilemmas which contemporary art museums are currently confronting.

Dilemma 1: Contemporary art museums define themselves through the architecture of their buildings. The architectural works often outshine the collections with the consequence that the building's operating costs exceed the budget for exhibitions and purchase of new artworks.

Dilemma 2: The art world seems to match the economy rules: growth is the only formula for success. Museums seem to afford increasingly larger buildings, their visitor numbers must increase annually, the collections are expanded and the size of the artworks is often fit only for gigantic halls. On the other hand, the visitor numbers have not increased to match the growth of art museums; statistics show that in Germany, in order to see all the art exhibitions, every German citizen should visit 9.3 exhibitions per day, every day of the year (Voss, 2015).

The art museums' visitors have also changed expectations and needs.

The most successful museums offer a range of experiences that appeal to different audience segments and reflect the varying needs of individual visitors. Research has shown that museum visitors seek experiences across the boundaries of learning, doing and enjoying.

Dilemma 3: Increased focus on special, temporary exhibitions or so called blockbuster exhibitions.

The audiences of temporary exhibitions differ in sociodemographic structure, behaviour and motivations from the visitors of permanent exhibitions. By definition, the character of the special, short-term attractiveness of temporary exhibitions influences the visitors' expectations and demands. As the focus moves from permanent and sustainable to short-term, blockbuster art exhibitions, the consequence is that not only are the visitors of permanent art exhibitions neglected but also the existing collections suffer from the lack of the necessary financial, manpower and marketing support. 
Although temporary and blockbuster exhibitions usually have an enormous visitor and media impact, they are viewed critically due to lack of sustainability. The event character of these blockbuster exhibitions is seen as counterproductive, as straw fires which do not promote cultural sustainability.

In addition to the present challenges and dilemmas, contemporary art museums face future challenges especially related to technology and the digitalization of their collections which are currently kept in archives.

Considering the factors and dilemmas listed above, and applying the model of the Vitruvian Man with the three dimensions of art, business and technology, the picture which contemporary art museums would present today shows an unbalanced combination (Fig. 3). Contemporary art museums are heavy on assets, the art segment by definition is overpowering; since art museums are forced to follow economy and business rules, the art segment slightly overlaps the business circle, but the art segment overlaps the technology segment even less, which nowadays is the smallest of all three circles.

While public contemporary art museums are heavily subsidized, the founding of private art museums is growing. Worldwide, there are 317 private art museums; about $60 \%$ of them register less than 20,000 visitors per year. In Germany, there are 42 private art museums. Most of them are the statement of passionate art collectors who want to find a stable home for and exhibit their own collection; they also want to leave a cultural legacy beyond their business enterprises. The average age of the founders is around 65 years old (Fairlie, 2013). About 27\% of private collectors own 500 to 1500 artworks, 30\% of collectors own more than 1500 works.

Many collect blue-chip artists; by far, the most popular collectibles found in private contemporary art museums are Warhol, Kiefer, Richter, Hirst and Picasso.

Private contemporary art collectors are mainly male, entrepreneurs, often without children, and aged between 40 and 70 years old. The younger collectors buy mainly contemporary art paintings and some works of modern art, especially Impressionists. The older collectors, 60 years old and above, are inclined to buy first according to their

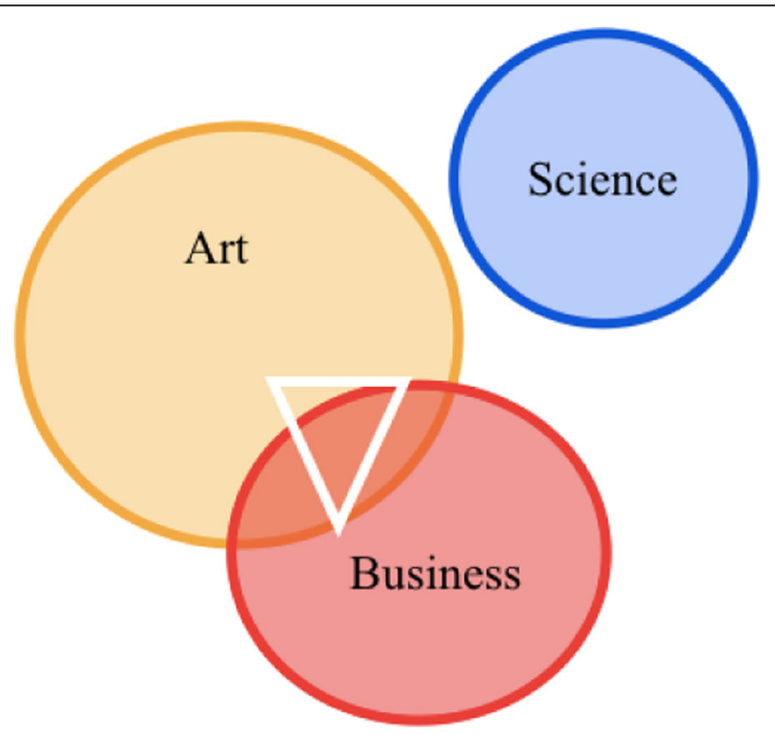

Fig. 3 Model of the Intersection of Art, Science and Business applied to Contemporary Art Museums. (C) 2016 Kunstmuseum Gehrke-Remund 
taste, then according to quality criteria, and they systematically buy according to the value of the artwork, in relation to the potential value increase of the artworks. According to Axa Art Study (2014), 80\% of collectors want to own and surround themselves with beautiful objects; $79 \%$ of collectors claim that they enjoy being involved in art and getting an in-depth knowledge of the contemporary art world by purchasing artworks, and $72 \%$ collect based on passion (Bußmann, 2015).

The contemporary art community is small and exclusive; it has been postulated that private contemporary art collectors actually buy artworks which are considered in fashion by the art community. Contrary to the art patrons of the Renaissance, the Axa Art Study indicates that the driving force to purchase a given artwork is not the passion the collector has for the artist, but rather the desire to possess a famous work that gives the collector reputation in his circle of millionaire friends and collectors. The Axa Study argues that the motivation to purchase artworks may be any combination of potential return on investment, aesthetics, love of art, challenge, intellectual exploration, social status, adrenaline rush, ego-building and public attention.

After 20 years of collecting art, most contemporary art collectors open their own museum, a decision often triggered by the fact that public museums reject the offer to receive the artworks of private collectors. This rejection is due to several reasons: the sheer size of the collection which would entail adding new wings to the museum to accommodate the donated artworks or the quality of the collection which is not in conformity with museums' standards. In May 2016, Austria declined to accept 7000 artworks from the collection of Mr. Essl because the works had been collected according to the subjective taste of the collector and did not conform to the museum's collection standards.

Private contemporary art museums not only share similar dilemmas as the public museums but have some additional challenges of their own. The primary paradox which private art museums are confronted with is the reason for their existence: the collectors' wish to display their collection to the public; however, over time, exhibiting their own collection is not enough to attract visitors to support the museum's operating costs. In order to compete, the private art museums are forced to exhibit blockbuster exhibitions taken on loan from other museums and collectors. A second paradox is that the private collectors are entrepreneurs in life; they found and fund their own private art museums, but when it comes to applying the business principles to manage their museums, most seem to fail in doing so. Statistics show that the revenues from admission tickets cover only $10 \%$ of the total public museums budget and about 30 to $40 \%$ of the budget of private art museums. In a 2010 interview, Frieder Burda admitted that the main financial challenges of exhibiting blockbusters on loan are the increasingly outrageous insurance costs. Frieder Burda, the heir of one of the largest publishing empires in Europe: the Burda Group, is the founder of the Burda Museum in Baden-Baden, Germany, the same city where the museum of the case is located. In the face of increasing financial pressure, contemporary art museums, regardless whether public or private, face the same survival challenge; this challenge is easily shared with any struggling industry which tries to find solutions by seeking new business models to support operations or tries to develop attractive offerings which appeal to the changing tastes and expectations of their customers. 
Private contemporary art museums are the initiative of private collectors who want to display their own collections and leave a legacy to future generations possibly with their names linked to the museum. In reality, the artistic and the business models of both public and private contemporary art museums are failing, resulting in a considerable number of private art museums struggling for survival. Germany, Switzerland and Austria report four examples of this struggle for survival which will be analyzed and discussed here; these four examples are relevant for the case in discussion. These four examples are the Burda Museum in Baden-Baden, Germany, the Diether Kunerth museum in Ottobeuren, Germany, the Beyeler Foundation in Basel, Switzerland, and the Essl museum in Vienna, Austria. On the tenth anniversary of the founding of his museum, Mr. Burda, whose museum was designed by the renowned architect Richard Meier and which has become one of the architectural landmarks of the city of Baden-Baden, declared his awareness to the press that his exclusive collection was doomed "to die in beauty" if his museum did not exhibit temporary exhibitions on loan to attract large numbers of visitors; moreover, his museum could no longer afford to show the blockbuster exhibitions of the past years such as Mirò and Chagall, nor could he personally afford to buy the works of blockbuster artists which have reached such outrageously high prices that only multi-millionaires and multi-billionaires can afford to buy and display in their museums (Meier-Grolman, 2016). In a small town in South-east Germany, the Kunerth museum was opened in 2014. The building designed by a famous architect reached a cost of 4.7 million Euros. The initial museum scope was to feature a permanent exhibition of the works of only one artist: Kunerth, after whom the museum was named, and to sell the works of the said artist in the museum shop, thus offering the visitors a combination of museum and gallery. The museum expected to cover the running costs from revenues derived from admission tickets, sales of Kunerth's paintings and sponsors, whereas the non-profit association, supporting the museum initiative, would manage the museum operations. Since its opening, the museum was plagued with artistic and financial problems; during the first year, three museum directors were hired and left. Eventually, a study was conducted to analyze the situation and make recommendations. On November 2015, the Mayor of the city announced the result of the expert analysis and the steps the city would take to turn the situation around. The report shows that the association was challenged financially and artistically in order to manage the museum; the financial model based on the sales of Kunerth's works and sponsors was unrealistic. Several of the hired museum directors had different ideas concerning the museum's strategy and management; hence, the position of museum director was eventually no longer filled. Mr. Kunerth took over the position of curator without having received the official institutional approval. As a result of the analysis, the city of Ottobeuren decided to immediately take over the ownership of the museum and realign the initial scope of the museum's concept by displaying, in addition to the permanent exhibition, two to four special exhibitions per year from other artists, thus falling back on the mainstream artistic model of every other contemporary art museum that must feature temporary exhibitions to boost visitors' numbers. One hundred miles South of Baden-Baden, there is the most visited art museum in Switzerland: the Beyeler Foundation Museum. Inaugurated in 1997 and designed by the Italian architect Renzo Piano, the museum is the legacy of the art dealer, Ernst Beyeler and hosts 200 works of his twentieth century art collection. One-third of the exhibition space is reserved for special exhibitions presented to complement the permanent collection thus following the 
mainstream model of displaying temporary exhibitions to attract visitors. In spite of the claim of being well-funded and the impressive number of over 300,000 visitors per year, only $65 \%$ of the 23 million dollar budget was covered by entry tickets. In 2015, the museum registered a loss of 5 million dollars; the city of Basel refused to increase the yearly three million dollar subsidy (Mensch, 2015). Near Vienna, Austria, the Austrian entrepreneur and art collector, Essl announced the closing of his museum effective July 2016. The museum, which opened in 1999, was the largest private museum in Austria; it was designed by a famous architect and hosted over 7000 contemporary artworks collected by Mr. Essl since the 1970s. Since the city of Vienna refused to take over Mr. Essl's collection, upon closing the museum, the building will be used as storage for the collection. These four examples of private contemporary art museums funded by entrepreneurs-private art collectors-share the same artistic model and eventually the same predicament of financial challenges. The artistic model of the four museums described in the examples, illustrated with the model of the Vitruvian Man, would result in an unbalanced focus on art, lacking a considerable overlap of the art segment with the business and technology dimensions.

Whether public or private, contemporary art museums not only exhibit the same artists, share the same business model of temporary exhibitions, exhibit the artworks in buildings designed by famous architects, but they also display art in the same aesthetic method in the style called "white cube" with the result that in New York, London, Basel or Baden-Baden, most contemporary art museums have polished wooden floors, plain white walls, light from above, glass and marble; a few wooden benches for visitors to sit on are usually located in the center of the rooms so they do not interfere with the artworks. The artworks themselves are hung with considerable space between each other so that each work can be observed without the distraction of other works and objects and small labels at the bottom right of the paintings give standard information about the artist, date, size, material of the work. Developed in 1930, the white cube concept of displaying art is still widely used today but increasingly criticized as anachronistic (Birkett, 2012).

The model of the Vitruvian Man with the intersection of art, business and technology applied to contemporary art museums shows that art museums are increasingly challenged to find new business models to generate revenues to cover operating costs, thus increasing the awareness that business principles need to be included in the design, management of the exhibitions and museums. The third element, technology, is still largely neglected or used mainly to offer the visitors some interactive activity via touch screens, apps or audio-guide content which can be heard on the visitors' own smart phones. However, the concept of presenting art as defined in 1930 is still the driving force for the exhibitions' curators who have not moved from object-focus to the visitor's experience-focus and from a focus on tangible, factual descriptions of the artworks to a focus on telling a compelling story accessible to the visitors which will make the visit to the museum memorable and will also attract audiences who usually do not visit museums. Even when technology is integrated in the exhibition with touch screens or apps, in an attempt to engage the visitors, the interactive offer is still object-driven not experience-driven, i.e. the vehicle for the information is more important than the content. 
The model of the Vitruvian Man with the three segments, their interactions and overlapping can be used first to assess the current contemporary art museums offerings, the gap existing among the three elements, and subsequently, it can be used as roadmap to move from object-driven offering to personal experience, feeling-driven sustainable proposition (Fig. 4).

\section{The case study: objective and methodology}

The paper analyses the case of a private German art museum Kunstmuseum GehrkeRemund ("Kunstmuseum"). The Kunstmuseum case demonstrates how entrepreneurs, newcomers in an exclusive, elitist industry can create value and deliver sustainable growth by designing their company's product offerings completely different from the features of the mainstream industry and how they focus on integrating art, business and technology elements into their final product.

The methodology employed in the case study includes the collection of the background knowledge of the museum, semi-structured interviews with the organization management, its associates and suppliers, evaluation of visitors' written feedback, observation of visitors behavior as well as the artifacts analysis of the museum's collection.

\section{The case of the Kunstmuseum}

The Kunstmuseum Gehrke-Remund in Baden-Baden, Germany, was founded in 2008 by two business people with a background in management, information technology, academia and a passion for art. Although one of the founders had an extensive formal education in art history in Italy and the other has a strong technical understanding of painting methods and techniques, neither had experience in museum nor art management,

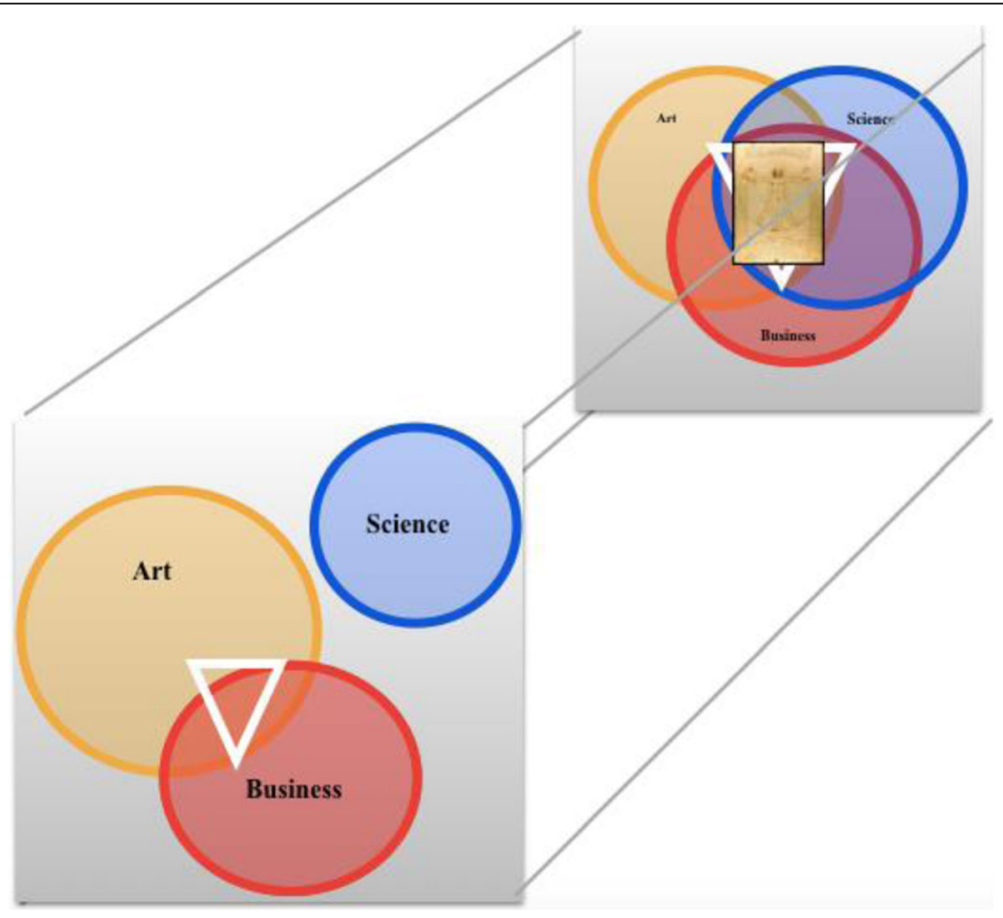

Fig. 4 Model of the Intersection of Art, Science and Business as Roadmap to create Sustainable Value. (C) 2016 Kunstmuseum Gehrke-Remund 
nor were they known in the small, exclusive circles of contemporary art galleries, museums, art historians, art critics and collectors. In the middle of the global financial crisis, the museum opened in February 2009; the museum is private and totally funded by the two owners. The idea to open a private art museum in Baden-Baden was determined by an external environment opportunity; starting in 2008, the city of Baden-Baden repositioned itself from a casino-spa city to a cultural city with health and beauty offerings. Not by chance, in the spring of 2009, two other private museums opened in Baden-Baden due to the initiative of two entrepreneurs; within 2 months in 2009, the offer of art museums in the city of Baden-Baden increased from two to five. The founders' motivation to start their own art museum was based on the disappointment they felt when visiting current contemporary art museums. Regardless in which part of the world, most contemporary art museums seemed to look the same, exhibit the same artists, have the same method to display artworks, and overall, the exhibitions have an anonymous and sterilized look and feel. The two founders consciously designed their museum and the artistic model by breaking every single self-imposed rule of mainstream art museums. Table 1 shows the list of features which depict the artistic model of mainstream contemporary art museums, and the right column shows the features which the Kunstmuseum Gehrke-Remund either changed, eliminated or added to arrive at the final concept. The list shown in Table 1 is only an excerpt of the actual list the two founders developed to design the elements of their concept, which included over 100 items. Eventually, there was only one element in common between mainstream museums features and the Kunstmuseum Gehrke-Remund; the paintings and exhibits would not be for sale.

Table 1 Museum and exhibition concept: comparison of features between mainstream art museums and the Kunstmuseum Gehrke-Remund. @ 2008 Kunstmuseum Gehrke-Remund

\begin{tabular}{|c|c|c|}
\hline & $\begin{array}{l}\text { Features of mainstream art museums } \\
\text { museum and exhibition concept }\end{array}$ & Kunstmuseum Gehrke-Remund \\
\hline 1 & Paintings and exhibits are not for sale & Paintings and exhibits are not for sale \\
\hline 2 & Building from famous architect & No, building is an old factory \\
\hline 3 & Building is owned by the private collector & No, building is rented \\
\hline 4 & Museum is in the center of the city & No, museum is not in the center but near the station \\
\hline 5 & Marble, glass, polished wooden floors & $\begin{array}{l}\text { No, the factory character was kept with cement floors, high } \\
\text { ceilings, exposed pipes }\end{array}$ \\
\hline 6 & Sparse wooden benches to sit on & $\begin{array}{l}\text { No, numerous, comfortable coloured chairs and armchairs } \\
\text { decorate the rooms }\end{array}$ \\
\hline 7 & Museums display temporary exhibitions & No, museum displays one permanent exhibition \\
\hline 8 & Museums exhibit several artists & No, museum is monographic \\
\hline 9 & Museums exhibit few works of each artist & No, museum exhibits all the works of one artist \\
\hline 10 & Museums display originals & $\begin{array}{l}\text { No, museum displays replicas licensed from the copyright } \\
\text { holder of the exhibited artist }\end{array}$ \\
\hline 11 & $\begin{array}{l}\text { Paintings are spaced according to the } \\
\text { White Cube hanging method }\end{array}$ & $\begin{array}{l}\text { No, the museum was conceived to look like an actual house, } \\
\text { the house of the selected artist, paintings are close to each } \\
\text { other with cross references }\end{array}$ \\
\hline 12 & $\begin{array}{l}\text { Each painting is labeled with data: title, } \\
\text { year, size, materials }\end{array}$ & No, paintings only have a sequential number \\
\hline 13 & Paintings are displayed alone & $\begin{array}{l}\text { No, next to the paintings, there are exhibits which refer to the } \\
\text { objects painted by the artist: dresses, jewelry, sculptures, } \\
\text { photos, furniture }\end{array}$ \\
\hline 14 & $\begin{array}{l}\text { Audio-guide content is written in art } \\
\text { historians' language }\end{array}$ & $\begin{array}{l}\text { No, visitors receive the catalogue on loan free of charge where } \\
\text { the story of the artist is told through the paintings in accessible } \\
\text { language }\end{array}$ \\
\hline
\end{tabular}


Probably, the most disruptive idea of the Kunstmuseum in Baden-Baden was to display replica paintings and not originals. Historically, replicas, reproductions and casts of classical sculptures were shown in American museums up to 1906 as they fulfilled the scope of educating the audiences. As museums became more focused on pure aesthetic experience, the educational scope was neglected; some experts even postulating that artistic and educational objectives were mutually exclusive (Birkett, 2012). In 2009, starting a private art museum based on the concept of replica paintings was unheard of and frowned upon by many art experts. The founders decided to display replicas instead of their own art collection of original paintings, because they wanted to tell the story of one artist and follow the artist's life through her paintings. Two artists were eventually in the short list of possible candidates: van Eyck (Flemish, 1390-1441) and Frida Kahlo (Mexico, 1907-1954). The two founders eventually selected Frida Kahlo because of her compelling, passionate and tragic story, even though the choice was financially much less attractive because the paintings of van Eyck are free from copyrights but the works of Frida Kahlo are still under copyright till 2024. The two founders formally requested the copyright holders of Frida Kahlo works, the country of Mexico, represented by Banco de Mexico, for the authorization to replicate all the known works of Frida Kahlo, a total of 127 items, to exhibit them in a museum in Baden-Baden. In 2008, the two museum founders received the authorization to replicate all the works of Frida Kahlo and thus became the first museum to ever receive such authorization to replicate all the works of an artist.

Table 2 shows a list of features as far as museum management is concerned. Not only for the concept of the museum but also for the management of daily operations, the Kunstmuseum Gehrke-Remund adopted atypical approaches in the art museum industry.

The Kunstmuseum has designed all the processes from the visitors' point of view, not from its own convenience or from a cost savings perspective. By using the Experience Map, the founders have designed the processes starting from the website to the time when the visitors arrive at the station, to the museum entrance; every single step is designed, tested and optimized from the eyes of the visitors. For operational excellence and efficiency, the founders have benchmarked the best methods from other industries: Starbucks for designing the Experience Map, IKEA for comfort and length of stay, Ritz Carlton Hotel for box office friendliness and competence, Disney parks for operational efficiency, and Apple for the care in packaging in the museum shop.

Tables 1 and 2 describe the de-bundling of key features of the museum industry and how the Kunstmuseum has defined themselves and its offerings and operations by doing the opposite of the industry standards. Table 3 shows the additional features which the Kunstmuseum has added to its offering and how these features add value and benefits for the customers but are impossible to copy by existing art museums even if they wanted to, because art museums have already defined themselves in assets, buildings, displays which are capital intensive, not flexible and hard to dismantle.

The concept of de-bundling the industry typical features and re-bundling new features into a completely new, innovative, disruptive model was developed by the founders of the Kunstmuseum in 2006, and they applied it to their own company in 2008.

The two founders designed the exhibition concept and experience by revisiting the method of Minimum Viable Product (MVP). The MVP is a method used to develop products resulting in the highest ROI versus the risk. Fig. 5 illustrates a typical new product 
Table 2 Museum management and operations: comparison of features between mainstream art museums and the Kunstmuseum Gehrke-Remund. ( 2008 Kunstmuseum Gehrke-Remund

\begin{tabular}{|c|c|c|}
\hline & $\begin{array}{l}\text { Features of mainstream art museums } \\
\text { Museum management of operations }\end{array}$ & Kunstmuseum Gehrke-Remund \\
\hline 1 & Private collector is rarely in his museum & $\begin{array}{l}\text { No, at least one of the founders and often both are in the } \\
\text { museum, they actively work and speak to the visitors }\end{array}$ \\
\hline 2 & $\begin{array}{l}\text { Guided tours are outsourced to outsiders } \\
\text { or part-time personnel with relative } \\
\text { knowledge of the exhibition }\end{array}$ & $\begin{array}{l}\text { No, guided tours are given exclusively by one of the two } \\
\text { founders who have in-depth knowledge of the artist }\end{array}$ \\
\hline 3 & $\begin{array}{l}\text { Museums rely heavily on personnel for } \\
\text { security }\end{array}$ & No, control is done by video cameras \\
\hline 4 & $\begin{array}{l}\text { Visitors are processed from box office to } \\
\text { coat room to the exhibition rooms }\end{array}$ & $\begin{array}{l}\text { No, every single step of the visitor is planned and designed } \\
\text { from the visitor's point of view using the method of } \\
\text { Experience Map }\end{array}$ \\
\hline 5 & Museums shops usually have pricey items & $\begin{array}{l}\text { No, museum shop prices range from } \$ 1 \text { to a maximum } \$ 45 \text {, } \\
\text { the average price is } \$ 9 \text { so most visitors find some souvenirs } \\
\text { to bring back home, shop items are displayed and explained } \\
\text { as if they were pieces of art }\end{array}$ \\
\hline 6 & Toilets are functional & $\begin{array}{l}\text { Beyond functional, toilets are decorated as if they were part } \\
\text { of the exhibition with photos, frames, antique carpets and } \\
\text { furniture. so that visitors take photos of the toilets }\end{array}$ \\
\hline 7 & $\begin{array}{l}\text { Coffee shop, museum shop and toilets } \\
\text { are often messy }\end{array}$ & $\begin{array}{l}\text { No, every single aspect and place in the museum is } \\
\text { considered to be an intrinsic part of the experience, } \\
\text { processes are designed so that visitors think they are the first } \\
\text { to visit the coffee shop, museum shop and toilets. For } \\
\text { example trash and hand towel bins are always emptied }\end{array}$ \\
\hline 8 & $\begin{array}{l}\text { Personnel at the box office check ID cards } \\
\text { for reduced tickets to students, seniors }\end{array}$ & $\begin{array}{l}\text { No, personnel at the box office are instructed not to check } \\
\text { IDs but to believe what the visitors say at face value }\end{array}$ \\
\hline 9 & Museums have rigid business hours & $\begin{array}{l}\text { No, if some visitors arrive up to } 30 \text { min early than opening } \\
\text { hours, the Kunstmuseum lets them in, it also allows them to } \\
\text { stay longer than the closing }\end{array}$ \\
\hline 10 & Employees adapt processes over time & $\begin{array}{l}\text { No, the museum designed strict SOPs for each step of the } \\
\text { visitors' experience, employees must follow the SOPs to the } \\
\text { extent of using exactly the same language and words to } \\
\text { give a short introduction to the exhibition or to answer } \\
\text { questions }\end{array}$ \\
\hline 11 & $\begin{array}{l}\text { Exhibition advertising budget is spent for } \\
\text { ads in magazines, billboards, radio }\end{array}$ & No, advertising is done exclusively in Google \\
\hline 12 & Visitors see the exhibition only once & $\begin{array}{l}\text { Returning visitors to the permanent exhibition represent } \\
\text { over } 50 \% \text { of all visitors; the exhibition is so complete, deep } \\
\text { and rich in content, continuously enriched with additional } \\
\text { exhibits beyond the paintings, that visitors return two to } \\
\text { four times }\end{array}$ \\
\hline 13 & Cameras are for control and security & $\begin{array}{l}\text { In addition, cameras are used to observe visitors behaviour, } \\
\text { flow of visitors through the rooms and make improvements }\end{array}$ \\
\hline
\end{tabular}

development starting from basic features of a feasible product; the features are mainly tested by early adopters, subsequently, the product is improved to the next level by adding value, then tested again, and eventually the last feature: delight, is added to the product.

The museum founders believe that the MVP concept can also be applied to start-ups; it provides entrepreneurs with a roadmap to plan the type and sequence of their offerings and the resources' allocation. However in the opinion of the two museum founders, the main drawback of the MVP method for developing new products or for developing the entire offering of a new company is that, while entrepreneurs are busy adding tangible features to make their company or product competitive, they risk never arriving at the level which will make the company competitive: the intangible features: the delight. As a consequence, they reversed the view and the approach to the MVP, 
Table 3 Kunstmuseum re-bundling of new features which other museums can hardly copy. ( 2008 Kunstmuseum Gehrke-Remund

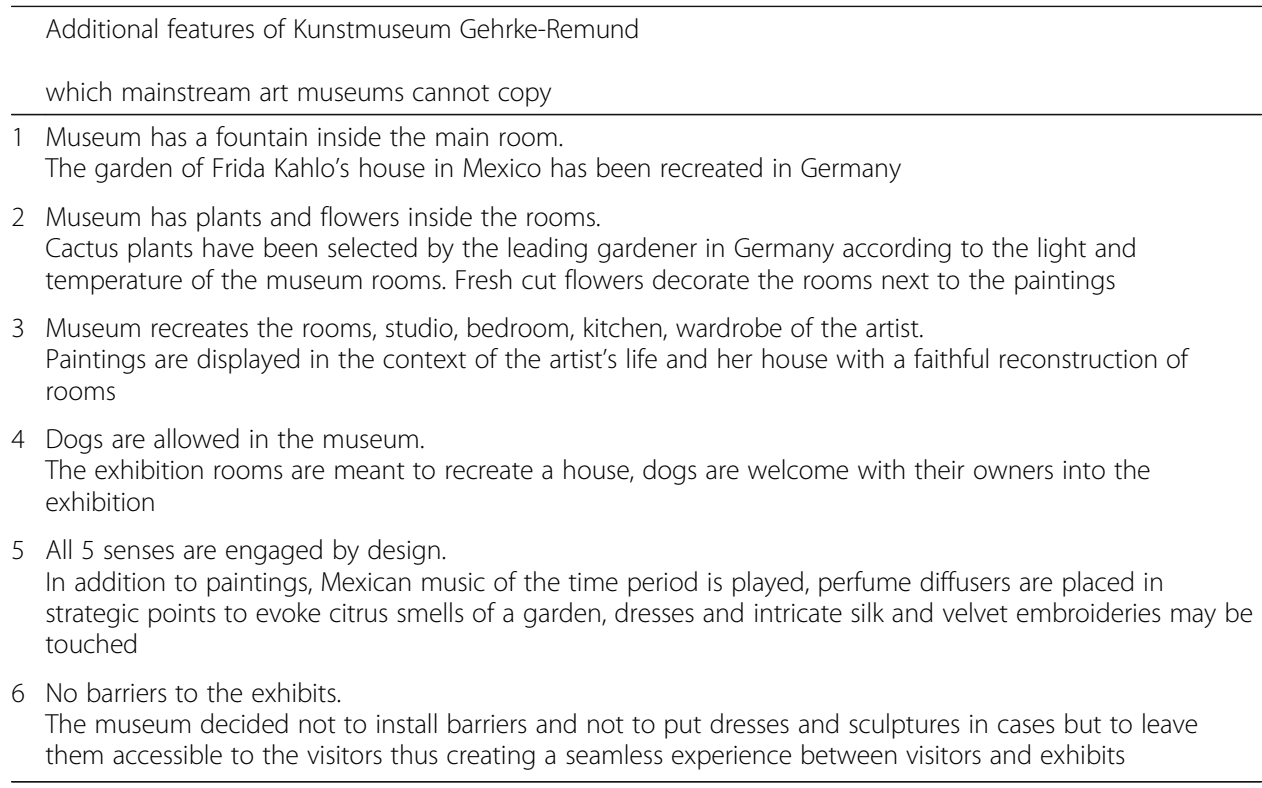

and they developed the features not from bottom to top but from left to right. The new product-new company needs to be designed, including from the start, a portion of all five segments; as a result, delight is designed and offered from the very start. Over time, the five elements are developed from left to right making the product more valuable, convenient to use, and at the same time, more delightful (Fig. 6). This method was used by the Kunstmuseum founders to offer a totally innovative art museum concept which from the outset was meant to engage not only the eyes of the visitors but all their senses and above all their hearts (Remund, 2013). As time passed, features were added to the initial concept, either additional exhibits or rooms to increase visitors' experience, but at the same time, the need to extend the delight was never lost from sight. Applying the revisited MVP allowed the museum founders to move from being object-

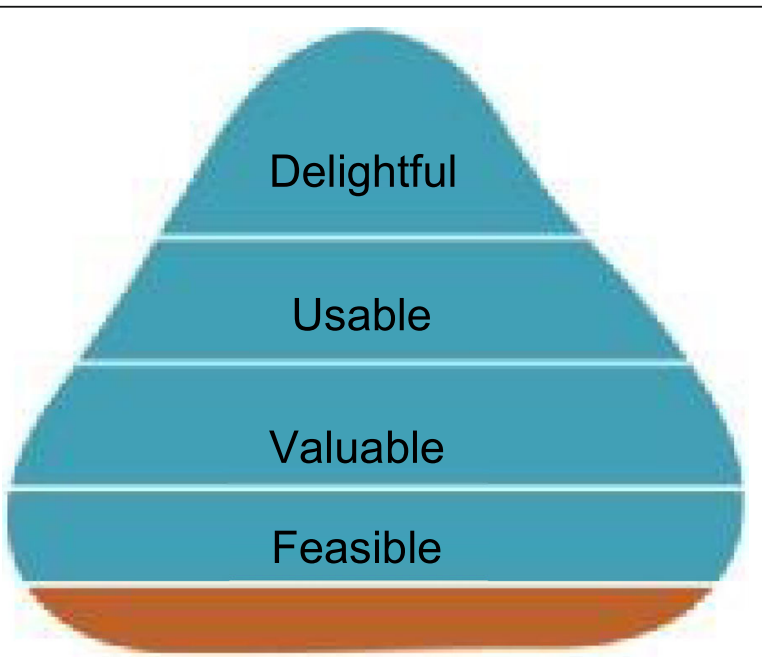

Fig. 5 Minimum viable product, traditional view 


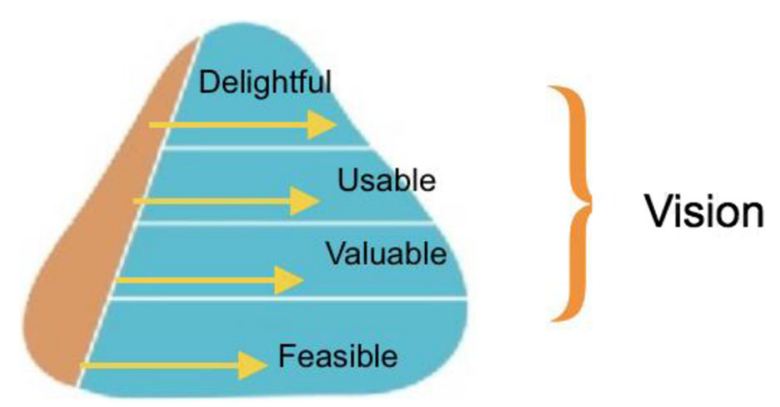

Fig. 6 Minimum viable product, entrepreneurial view for innovation and sustainable competitiveness. $\odot$ 2016 Remund

driven to being emotion and feeling-driven by design. The approach to develop the new product or enterprise from left to right by designing delight from the outset facilitates the organic, balanced, sustainable growth of the new enterprise.

By applying the model of the Vitruvian Man to the Kunstmuseum artistic and business model, and with the support of the revised concept of MVP, the three elements of the Vitruvian Man have been considered in the design of the museum from the very start, and they have been developed so that the overlapping of the three elements has increased over time.

The art elements for the museum meant not only the obvious selection of the artist and the execution of the artworks but also the founders understanding and extending art in the way the company concept and products were developed, art as originality and creativity, art as beauty in every aspect of the company, passion, fun, happiness, intuition, harmony, and emotions, the art of designing the customers' experience and the art in presenting and packaging the items in the museum shop. All the elements just mentioned can be applied to any start-ups. The business elements applied to the museum include the ultimate vision for the company and the product, business ethics, the selection of the business model, the business and management tools for decision making, design processes and SOPs, market and customers' knowledge, early recognition of trends, ability to finance ventures, ability to form win-win partnership, ability to develop the company infrastructure and planning for growth. Whereas most of the elements listed above could be easily copied by other museums, the vision and the ability to create a delightful visitor experience is impossible to copy. The technology elements applied to the museum include application of state-of-the-art replication methods, painting techniques, use of technology versus personnel for security, control, visitors' behavior research, state-of-the-art website, social media presence, ability to answer customers' enquiries $24 / 7$, data mining, database of media and stakeholders, scalability, standards, perfection in execution and metrics, logic, relevance, efficiency, reliability and lack of deviation in quality standards. The overlapping of the three dimensions results in creating artworks and beauty in every single aspect of the company, the products and the processes regardless in which industry the new company operates. Using technology also for non-technology products and enterprises results in perfect execution and using business principles results in a sustainable innovative new company.

Although art critics and historians may disapprove of the use of replicas in an art museum and the unconventional additional features, the visitors have given a delighted 
response to the concept which has also attracted people who traditionally would never visit museums. The visitors' comments in the Kunstmuseum guest books show that the customers feel like they belong in the museum and the environment which the museum offers them. A visit can last 2 to 3 hours versus an average 40 min in other art museums in Germany; 50\% of visitors are return visitors or word-of-mouth visitors. In 2012, 3 years after its foundation, the Kunstmuseum was listed by the Mexican National Council for Culture and Art as one of the two treasures of the Mexican culture that can be seen in Germany (Gleason, 2010). In 2014, the museum appeared in the history of Mexico told through the treasures of the Mexican culture which can be found in European museums (Gleason, 2014). The building blocks of the Vitruvian Man model applied to entrepreneurship and this innovative model applied to a private art museum result at the same time in a unique concept, which is difficult to copy by competitors but applicable and transferable to other industries and businesses by other entrepreneurs who want to create sustainable value.

\section{Conclusions}

The main conclusion of this paper is that art, science and their capacity to use technology, as well as the specific strategies and organizational decisions of the company are the crucial elements that can create a non-imitable, idiosyncratic mixture, which can achieve and sustain competitive advantages. The main implication of this analysis is that entrepreneurs can no longer develop a uni-dimensional product offering and that design thinking must spread across functions to embrace art, science and technology for a sound business proposition.

The keyword which unites all is art-the art of cultivating, producing, marketing science as a tentative art, on a daily basis, which makes it possible to understand, from its analytical procedures, parts of reality and the art absorbed in learning and which expresses all that we are and what moves our lives and which we do not completely understand. They are all forms of art, experience and the art of living in their diverse dimensions.

From the diverse aspects of management thinking, with various forms of expression and different sensitivities, as Schumpeter $(1934,1950)$ expressed in reference to the capacity for the discovery and exploitation of opportunities, or Penrose (1959) when he refers to the executive's mind as one of the essential resources of the company. This is creativity, the skill to discover a unique and idiosyncratic combination with the corporate technology, and with its organization and strategy which enable the best proposals and initiatives to succeed concerning the businesses in the ecological environment in which they compete.

Although the analysis of the museum described in the case study has achieved its goals, the authors are aware of its limitations which may be conducive to further research projects. First, the semi-structured interviews of the organization were conducted in a small sample due to the size of the museum staff, therefore generalizations are difficult to make. Second, a key provider of the museum information and knowledge is the founder of the museum, which may have resulted in a certain level of subjectivity. Third, it would be interesting to explore to what extent the roadmap and the model developed by the Kunstmuseum, and illustrated in Fig. 6 of the MVP can be replicated in practice by other entrepreneurs in other industries, an issue which needs to be validated. This could be the starting point of future research projects. 
Authors' contributions

All the authors have contributed equally in the development of this paper. All authors read and approved the final manuscript.

\section{Competing interests}

The authors declare that they have no competing interests.

\section{Publisher's Note}

Springer Nature remains neutral with regard to jurisdictional claims in published maps and institutional affiliations.

\section{Author details}

${ }^{1}$ CETYS University, Calz. Cetys S/N, Rivera, 21259 Mexicali, BC, Mexico. ${ }^{2}$ Universitat Politècnica de València, Camino de Vera, s/n, 46022 Valencia, Spain. ${ }^{3}$ Kunstmuseum Gehrke-Remund, Gueterbahnhof Str. 9, 76532 Baden-Baden, Germany.

Received: 29 January 2017 Accepted: 19 July 2017

\section{Published online: 14 August 2017}

\section{References}

Birkett, W. B. (2012). To infinity and beyond: A critique of the aesthetic white cube, Theses. Paper (Vol. 209).

Bußmann, H. G. (2015). Die eigene Kunstsamm/ung: Uber Motive und Sammlertypen. http://www.kunstmarkt.com/pagesprz/ kunst/_d345070-/show_praesenz.html. Accessed 29 Jan. 2017.

Campbell, S. (2016), Leonardo Da Vinci's Life. http://www.davincilife.com/vitruvianman.html. Accessed 29 Jan 2017.

Child, J. (1972). Organization structure, environment and performance: The role of strategic choice. Sociology, 6, 1-22.

Child, J. (1997). Strategic choice in the analysis of action, structure, organizations and environment. Organization Studies, $18,43-76$.

D'Angelo, M. and Schlenker, K. (2015), Is there a bubble in the art market? http://www.huffingtonpost.com/ Madelaine-dangelo/is-there-a-bubble-in-the_b 8630434.html. Accessed 29 Jan 2017.

Fairlie, R. W. (2013). Kauffman Index of Entrepreneurial Activity. http://www.kauffman.org/ /media/kauffman_org/ research\%20reports\%20and\%20covers/2013/04/kiea_2013_report.pdf. Accessed 29 Jan 2017.

Get2growth (2015), How many startups are there? http://get2growth.com/how-many-startups/. Accessed 29 Jan 2017.

Gleason, M. (2010). Mexico en Alemania y Austria. Mexico City: Educal.

Gleason, M. (2014). Mexico insólito en Europa. Mexico City: Fogra Editorial de Mexico.

Hayton, J. C. (2005). Promoting corporate entrepreneurship through human resource management practices: a review of empirical research. Human Resource Management Review, 15, 21-41.

Hayton, J. C. (2006). A competency-based framework for promoting corporate entrepreneurship. Human Resource Management, 45(3), 407-427.

Martin, C. J. (2016). The sharing economy: a pathway to sustainability or a nightmarish form of neoliberal capitalism? Ecological Economics, 121, 135-153.

Meier-Grolman, B. (2016). "Zehn Jahren Museum Frieder Burda in Baden-Baden", Südwest Presse Online. http:// www.swp.de/ulm/nachrichten/kultur/Zehn-Jahren-Museum-Frieder-Burda-in-Baden-Baden;art4308,2701048. Accessed 29 Jan 2017.

Mensch, C. (2015). "Schwarze Kunst und Rote Zahlen". Schweiz am Sonntag. http://www.schweizamsonntag.ch/ressort/ basel/schwarze_kunst_und_rote_zahlen/. Accessed 29 Jan 2017.

Mont, O. (2004). Institutionalisation of sustainable consumption patterns based on shared use. Ecological Economics, 50, $135-153$.

OECD (2015). Entrepreneurship and business statistics. http://www.oecd.org/std/business-stats/. Accessed 29 Jan 2017. Penrose, E. (1959). The theory of the growth of the firm. Oxford, Basil Blackwell and New York: John Wiley \& Sons.

Raue, P. (2010). "Sammeln wir die falsche Kunst?". Zeit Online. http://www.zeit.de/2010/03/Kunstmarkt. Accessed 29 Jan 2017.

Remund, M.C. (2013). "Largest exhibition of the life and art of Frida Kahlo makes U.S. premiere in San Diego". Business Wire. http://www.businesswire.com/news/home/20131007006586/en/Largest-Exhibition-Life-Art-Frida-Kahlo-U.S. Accessed 29 Jan 2017.

Samuelson, P. A. (1947). Foundation of Economic Analysis. Cambridge: Harvard University Press.

Saya, A. (2015). "Mehr Aufbruchs-Als Krisenstimmung". Stuttgarter Zeitung. http://www.stuttgarter-zeitung.de/inhalt. symposium-grenzen-des-wachstums-mehr-aufbruchs-als-krisenstimmung.76a6553e-54be-4ba4-823d-9710e6b746b3. html. Accessed 29 Jan 2017

Schumpeter, J. A. (1934). The theory of economic development. Cambridge: Harvard University Press.

Schumpeter, J. A. (1950). Capitalism, socialism and democracy (3rd ed.). New York: Harper \& Row.

Shane, S., \& Venkataraman, S. (2000). The promise of entrepreneurship as a field of research. Academy of Management Review, 25, 217-226.

Statistic Brain (2015). Startup business failure rate by industry. http://www.statisticbrain.com/startup-failure-by-industry/. Accessed 29 Jan 2017.

Sutton, B. (2016). "Crunching the numbers behind the boom in private art museums". Hyper allergic, http:// hyperallergic.com/269548/crunching-the-numbers-behind-the-boom-in-private-art-museums/. Accessed 29 Jan 2017.

Tracey, P., Phillips, N., \& Jarvis, O. (2011). Bringing institutional entrepreneurship and the creation of new organizational forms: a multilevel model. Organization Science, 22(1), 60-80.

Voss, J. (2015). "Vielleicht gibt es einfach zu viele Museen. Frankfurter Allgemeine Zeitung. http://www.faz.net/aktuell/ feuilleton/kunst/ein-gespraech-mit-christiane-lange-13844184.html. Accessed 29 Jan 2017.

Weick, K. E. (1969). The social psychology of organization. Reading: Addison Wesley. 